the cliff. After a careful inspection I identified these as Violet-green Swallows, a species normally found breeding several hundred miles westward in the mountains.

[Ed. Note: For a nesting record in the Saskatchewan Cypress Hills see Blue Jay 27:144-145, 1969.]

Two Mule Deer were seen on the way to the river and besides the passerines noted on July 3 Black-capped Chickadees and Mountain Bluebirds were noted. I swam across the river and found at least six Bullock's Orioles in a grove of trees. Because I had left my binoculars on the other side, I had to get close to identify them, but they proved to be fearless and I was able to approach to within several feet of them.

On the steep slopes of the Valley I heard a cascading song that I recognized at once as a Canyon Wren, a bird I had heard in the Okanagan Valley in British Columbia in the spring. The tumbling melody of notes that make up its song could easily be distinguished from the Rock Wrens and nearby Sprague's Pipits. I searched for the songster for some hours but without success. I was disappointed not to actually see it, but was still elated to have identified it. The only previous occurrence of the Canyon Wren in Canada was in the Osoyoos Arid Biotic region of the southern Okanagan Valley.

A few miles north of the Valley I saw a pair of shorebirds that I believe were Mountain Plovers. I am not certain, however, for when I stopped to check they flew off across the prairie. This species has been previously recorded by Dr. J. Dewey Soper at Wildhorse, about 25 miles away (four on June 22, 1941), and by Cleve R. Wershler at Elkwater, about 45 miles away (two on June 12, 1966). (Dr. Soper also reported one near Bracken, Saskatchewan on June 5, 1939).

August 28 - There were a hundred ducks gathered on the Milk River, apparently massing for migration. Three species not previously seen in the area were: Sparrow Hawk, Tree Swallow and Robin. At the river I found a Brown Thrasher bathing along with several Rufous-sided Towhees.

\title{
WHITE-TAILED DEER IN NORTHERN SASKATCHEWAN
}

\section{by $\mathbf{E}$. Otto Höhn, University of Alberta, Edmonton, Alberta}

White-tailed deer are reported by Beck (1958) as occurring in southern and central Saskatchewan, with Prince Albert National Park as the most northern locality named in connection with its distribution in the province. The publication cited gives a similar northern boundary for the Saskatchewan range of the mule deer, but in a later publication, the author (Beck, 1964) records the identification of deer tracks at two points on the south shore of Lake Athabasca, near Beaver Point, July 1960, and near William Point, July 1961. No deer were seen, but the tracks were attributed to mule deer as the most likely species in the area.

On July 26, 1971, I found two very clear deer tracks on the sandy shore of Lake Athabasca, a few miles west of the Alberta/Saskatchewan border. In view of the distribution maps of the white-tailed and mule deer in Hall and Kelson (1959) and those prepared for their range in Alberta by $R$. Webb in 1959 and reproduced in Soper's "Mammals of Alberta" (1964), I would also have interpreted these tracks as probably those of mule deer.

However, when $I$ was at Uranium City a few days later, a taxi driver told me about two "jumping deer" (in my experience, a vernacular name for the white-tailed deer) he had seen crossing a road near the town earlier that month. Later Mr. J. A. Macauley, Conservation Officer at Uranium City wrote to me that on July 20, 1971, he saw two white-tailed deer beside the road at Ace Lake, five miles east of 
Uranium City. His letter mentions the waving white tails of these deer and their graceful bounding gait when in full flight, both of which he contrasted with these features in mule deer. Additional points of evidence of the presence of deer, of one of the two species mentioned, in this area are a statement given to me by a local Indian in January 1970, that deer occurred there and a deer track I found in fresh snow on November 27, 1971, within a mile of Eldorado.

E. Kuyt has reported the occurrence of white-tailed deer about Fort Smith, Northwest Territories in 1966 and more recently (1971) he has noted further white-tailed deer and also mule de $^{\sim} r$ sightings in that area.

To obtain relevant information about an area between Fort Smith and Uranium City, I wrote to the game warden at Fort Chipeweyan, Alberta. After enquiring from a number of trappers, Mr. H. E. Schaber reported (August 1971) that a Mr. F. Ladouceur toid him he had shot two whitetailed deer in the Athabasca delta about 1963 . He had kept their tails for later identification as these deer were strange to him. Apart from this, there were no deer sightings and only the rare finding of deer tracks near the Alberta/Saskatchewan boundary (presumably on the south shore of Lake Athabasca).

Webb's deer distribution maps referred to above show the mule deer as occurring sporadically throughout northeastern Alberta and white-tailed deer as found, sporadically, in that area only along the Athabasca river to Lake Athabasca. The recent Fort Chipeweyan information does not indicate any change from this.

Mule deer about Fort Smith do not indicate a marked change of the range of this species, but Kuyt's 1971 report suggests that they are now of more than sporadic occurrence there.

However, as Kuyt pointed out, the presence of white-tailed deer in the Fort Smith area constitutes a considerable northward extension of the species range and this applies equally to those seen about Uranium City.

Presumably, these deer reached the Fort Smith area by following the Slave River from the Athabasca delta. Those about Uranium City may have come from the same delta and followed the north shore of Lake Athabasca, but if so their apparent absence from the Fort Chipeweyan area, between these two points, is puzzling. An alternative approach to Uranium City is directly from the south. If long northward moves occur in winter, crossing the frozen lake would present no problem. However, I would imagine that northward range extensions result from journeys made in summer. The map shows that a crossing between Beaver Point on the south shore of Lake Athabasca and the islands off the tip of the long peninsula which extends into the lake southwestward from the vicinity of Uranium City involves, because of intervening Long Island, a maximal stretch of open water of only about eight miles. Deer can probably swim such a distance.

There are also some less spectulative questions raised by the foregoing. One is whether there are mule as well as whitetailed deer about Uranium City. Another is, which species of these deer occur on the south shore of Lake Athabasca.

\section{Acknowledgment}

My summer, 1971, journey to Lake Athabasca was supported by a grant from the Boreal Institute of the University of Alberta.

\section{LITERATURE CITED}

Beck, W. H., 1958. A Guide to Saskatchewan mammals. Sask. Nat. Hist. Soc. Spec. Publ. No. 1.

Beck, W. H., 1964. Record of mammals in the Lake Athabasca area, Saskatchewan. Blue Jay $22: 164-172$.

Hall, R. E .and Kelson, K. R., 1959. The Mammals of North America, Vol. 2, pp. 1005 and 1009, Ronald Press Co. New York.

Kuyt, E., 1966. White - tailed deer at Fort Smith, N.W.T. Blue Jay $24: 194$.

Kuyt, E. 1971. Possible occurrence of cougar near Fort Smith, N.W.T. Blue Jay 29 :142143.

Soper, J. D., 1964. The Mammals of Alberta, pp. 345 and 349 . Queen's Printer, Edmonton. 